\title{
"Network Wars" as a New Type of Deviation Processes in the Modern Electronic and Information Society in the Context of Social and Economic Security
}

\author{
Irina Sovetovna Karabulatova1
}

Pavel Vladimirovich Barsukov ${ }^{1}$

Ilnur Vazirovich Akhmetov²

\section{Mamatelashvili Olga Vladimirovna²}

Faiz Farvazovich Khizbullin²

${ }^{1}$ Institute of Social and Political Research of the Russian Academy of Sciences, 32A, Leninsky prospect, Moscow 2Ufa State University of Economics and Service, 450078, Ufa, Chernyshevsky St., 145

\section{Doi:10.5901/mjss.2015.v6n6s3p150}

\section{Abstract}

Incapacity of the existing global and regional architecture focused, especially in the Euro-Atlantic region, only on the North Atlantic Treaty Organization, and also imperfection of legal tools and mechanisms more and more create a threat to international protection in general, and to the Russian Federation in particular. A present stage in the world community development was marked by rapid globalization of all spheres of life which has absorbed countries and the whole continents as a result of which the system interdependence of events happening in the world space has created. This circumstance has aggravated the interstate contradictions connected with irregularity of the development, the deepening of a gap between the standards of well-being of countries (Karepova, et al, 2015; Ryazantsev, et al, 2014; Ryazantsev, et al 2015 \& Ryazantsev, et al, 2015). Values and models of the development became the subject of the global competition (Gerber, 2010; Gabdrafikov, et al, 2015 \& Dixon, et al, 2015), and, therefore, the grounds for evolution of a legal base in the context of the global competition appears, that is necessary for understanding of forces which influence the law on a competition at the international level. The rapid scientific and technical progress has led to a change of the environment and the increased role of information in citizens' everyday life that leads to a change of parameters of the social and economic security (Zamaletdinov et al, 2014 \& Bugeja, 2015). Along with the positive influence on production and active processes, information and information technologies create the huge opportunities to manipulate individual and mass consciousness, taking economic and material resources, a change and taking by the political power in regions and the whole countries. Authors give the grounds and description of the conceptual model of "a network war" as an innovative mechanism of realization of the geopolitical strategy of the main world powers in the first decade of the XXI century on the example of the analysis of the main stages of foreign policy activities of the western countries for destabilization of a situation in Ukraine in 2013-2014. Authors point out the factors which will define the future of globalization, analyze a phenomenon of "network wars" as an effective mechanism on ensuring the influence and forecasting of decisions on the global social and economic management.

Keywords: concept of "network wars", foreign policy of the state, social and economic security, deviation processes, globalization.

\section{Introduction}

Strengthening of new centers of the economic growth and political influence has created a completely new geopolitical situation. A tendency to the search of the solution of existing problems and the settlement of crisis situations on the regional basis without participation of out-of-area forces is formed. At the same time the vulnerability of all members of the international community in the face of new calls and threats has increased (Decree of the President of the Russian Federation issued on May 12, 2009 №537 "On a strategy of the national security of the Russian Federation till 2020).

For example, having eliminated a geopolitical competitor in the face of the USSR, Americans have started to harden political and economic positions in the world, thus events of the end of the XX and the beginning of the XXI century show that the USA are aimed at the global domination defining its national interests as primary in relation to the interests of other members of the world community.

In this period in the American internal political structure there was a redistribution of traditional state functions in 
the field of economics, high technologies, arms, etc. between the state investigation and business. In the course of reforming of reconnaissance community of the USA there were basic changes in the legislation and the strategic installations embodied in new functionality of confidential departments.

The process of interaction strengthening of the state intelligence services with security services of the large corporations has expanded very quickly. Adjustment of data exchange and realization of joint expeditious actions on many parameters were favorable both to the state and private companies.

Such factors as simplicity in the decision by specific means of many tasks, the ability to avoid bureaucratic and technological obstacles and to save time, and also a main role of CIA and other intelligence services of the USA in rendering the successful destructive external impact on the USSR and countries of a socialist camp have led to the fact that they had the tasks which were earlier officially not carried out by intelligence services, were set: providing priority positions of the American business at the international and internal markets; security and stability of financial streams going to the country; the assistance to establishment of the favorable rules for the USA in the world trade and business.

Reforms of reconnaissance community of the USA of 90-200-s were characterized by the partial transfer of its functions to effective and economically interested multinational corporations. Business conduct by nontraditional methods which are based on the usual competition, but by forces and means of intelligence services that has led the American corporations to the leading positions in the world, and a global character of their national interests was a serious incentive to realize the interaction of a private sector with intelligence services.

Finally intelligence services of the USA (as well as of some other countries) have stopped now to be only the tool of the government and have reached a position of independent players of the world politics and economics (Syomin, 2011). Indisputable is the fact that Russia, Belarus, until recently Ukraine, and also other separate states which did not join NATO and aimed at keeping the political sovereignty, are the objects of geopolitical ambitions of the USA and their allies.

The purposes of the USA concerning such countries are extremely accurate: the transformation into a remotelycontrolled partner, providing a free access of multinational corporations to the resource base, the concentration in their territory of harmful productions and storages of waste products.

For the achievement of these purposes Americans quite often resort to the use of the state armed violence (i.e. commission of an act of armed aggression against the sovereign state and the population), an example of that are military operations of NATO in Yugoslavia, Iraq and Afghanistan, Libya.

Along with it, events of the last years show that realization of revolutionary scenarios without the initial direct use of armed forces of the USA and NATO member states (Serbia, Georgia, Ukraine, Kyrgyzstan, Algeria, Tunisia, Morocco, Libya, Syria, etc.) becomes a key tool of the foreign policy of Washington on rendering the impact on the internal political situation in the countries-objects of the interest.

This tactics together with rendering the diverse (economic, political, social, military character, up to threats of the direct military intervention) influence has got the name "soft power" - a soft force where behind backs of protesters there were American and European ideologists of the democracy advance.

\section{Materials and Methods}

In conditions of the sharply aggravated foreign policy situation for the Russian Federation caused by fratricidal events in Ukraine and attempts of the pro-American establishment to fabricate concerning our country proofs of a direct military intervention for the purpose of occupation of a part of the Ukrainian territory, the analysis of the course of events of the Ukrainian crisis in 2013-2014 from a concept position of "network wars" is actual.

A number of documents of the USA military-political leadership from 90 - $s$ to the beginning of the 2000s years (for example, a plan for of the USA armed forces construction "Joint Vision 2010") shows that during this period in depths of the scientific and political establishment of the USA following the belligerent line in the national foreign policy a concept of "network wars" which present a set of views, principles, approaches and methods of the USA national interests realization in the modern world was developed.

In particular, it is meant that in the XXI century the main threats of the USA national security will proceed not only from regular armies and special services, which structure and activity is based on views and principles of the middle-end of the XX century, but also from the state and non-state organizations of other countries, terrorist and other criminal organizations organizationally representing network structures. A special term "the segmented, polycentric, ideologized network" was used for a designation of similar structures (Segmented, Polycentric, Ideologically integrated Network SPIN). As the symmetric answer Americans have the task of creation of operated be themselves SPIN that defines such concept as a "network war" that means the antagonism between its "networks" and the opponent's "networks". 
This concept defines a "network war" as a new way of conducting the conflicts at the social level without the traditional use of the military force when protagonists use network organization forms and connected with it doctrines, strategies and technologies which correspond to the era of the electronic and information society (Dugin, 2006).

Thus, performances and publications in electronic mass media focused on the perception restructuring by recipients of social and economic, military-political events are the material for the analysis.

\section{Results}

For a "network war" operation realization Americans at the first stage:

1. Define expediency and possibility of carrying out "soft" and "power" options with the involvement of armed forces, police and irregular paramilitary groups, and also the moment of connection of these forces in the operation scenario, make plans with allies.

2. Carry out the constant and continuous information providing, monitoring and control of a political situation in the world.

3. Coordinate a planned operation with intentions to solve real or imaginary problems of the civil society, give to their plans a humanitarian status, declare to the international community about their aspiration to improve a situation in the country-object of the influence with the purpose concerning providing the legitimacy of external intervention in internal political life of the country.

The subjects ("actors") of the "network" influence are:

1. U.S. intelligence community and other government bodies of the USA, other connected with them organizations, national finance and industrial corporations and establishments.

2. Interstate and international organizations, unions, etc. (NATO, OSCE, etc.).

3. International non-profit non-governmental organizations.

4. Steady groups of persons, political parties, unions including the steady criminal and terrorist groups, etc.

A "network war" is, eventually, a certain qualitative condition of the international environment within which actors interact, thus their interaction within the global framework oh which it has a conflict character.

Thus, events of the internal political crisis in Ukraine were developing on the following scenario developed by Americans with the gradual involvement in the process of new actors.

In November, 2013 a decision of the government of Ukraine to stop the process of the Agreement on association with the European Union signing was made. This decision has led to a mass protest action in the center of Kiev, and also in other cities of Ukraine which have got on social networks and mass media the name "Euromaidan" by analogy with events in 2004.

The protest activity has sharply accepted an anti-presidential and antigovernmental character after the Vilnius summit of "East partnership" (November 28-29), the dispersal of the tent town of opposition in Kiev and passage on January 16, 2014 by the Verkhovna Rada of laws providing sanctions toughening for participation in mass riots.

The opposition leaders' statements published in materials of mass media presents that it is necessary to refer the social injustice, a huge polarization of the income and a standard of living of the population of Ukraine and the corruption revelry penetrating the executive and judicial authority, the law enforcement agencies to the main reasons of escalation of events development. On 30 November, 2013 the formation of groups of self-defense for protection of the Euromaidan has begun.

The diverse nationalist groups (UNA-UNSO, "Trizub", "Patriot of Ukraine" and others) made the far-right extremist association "Right Sector" considering the Euromaidan as a convenient occasion to the start of the "national revolution" which, as the leader of the "Right sector" Dmitry Yarosha says, must be ended with the "full elimination of the mode of internal occupation and receiving the Ukrainian national state with the system of comprehensive national democracy".

On January 19, 2014 in Kiev after the regular assembly convoked by leaders of parliamentary opposition (VO "Batkivshchina", UDAR, VO "Svoboda"), collisions of radical protesters with groups of militia began. The opposition has demanded resignation of the government and continuation of the European integration. In next days the oppositional protesters in the Ukrainian regions have proceed to occupations of buildings of regional administrations. In the west of Ukraine these actions made success whereas in regions of the central Ukraine these attempts were stopped by law enforcement agencies. As a result of power opposition in the center of Kiev, occupations of office buildings and authorities in the capital and the regional centers which have begun, the creation of parallel authorities, the organization of informal power structures Ukraine has appeared on the verge of introduction of the state of emergency, the loss of territorial integrity and economic collapse.

Negotiations between the president of Ukraine V. Yanukovych and the leaders of parliamentary opposition which 
were going several days, have led to concessions from the authorities: there was convoked the emergency assembly of the Verkhovna Rada which has voted for cancellation of a number of laws of January 16 and has adopted the law on amnesty for participants of events in November, 2013 - January, 2014 on January 28 the president has accepted the resignation of the prime minister Nikolai Azarov and the cabinet which continued to carry out duties before the formation of a new structure of the government. Despite it, protest actions have continued. The opposition made demands of the return of Ukraine to the parliamentary and presidential system of government and constitution of 2004. On 12 February the president Yanukovych has agreed to go for the formation of the coalition government. By 15 February within the amnesty all earlier detained participants of protests were released. In the night from 15 to 16 February buildings of regional administrations were unblocked by the protesters, in Kiev the protesters have partially vacated the Grushevsky Street and the building of the city administration. At the same time on 16-17 February the VO "Maidan" and the "Right sector" have declared the preparation of a "peaceful attack" to the Verkhovna Rada.

On 18 February there was a sharp aggravation of a situation which was followed by mass bloodshed. At the assembly of the Verkhovna Rada the opposition has demanded an immediate return to the parliamentary presidential government and the recovery of the constitution of 2004. At the same time in Kiev protesters' attacks with the police, which was a member of the meeting, were resumed, that has led to the death of tens people. The situation in the west of Ukraine became extremely aggravated.

On 21 February under the pressure of the West countries Yanukovich has made concessions and has signed an agreement on settlement of the crisis in Ukraine with the opposition providing, in particular, an immediate (within 2 days) return to the Constitution in redaction of 2004, the constitutional reform and carrying out early presidential elections no later than in December, 2014. On the same day Yanukovich has left Kiev.

The new Ukrainian power has got the recognition from the European Union and the USA. The official European Commission representative Olivier Bailli characterized the decision of the Verkhovna Rada to give A. Turchynov president's duties as the "democratic and lawful", and the ambassador of the USA in Ukraine Jeffrey Payette has declared: "We reject any hints concerning the fact that there is the revolution here, and that legitimacy of the incident is allegedly questionable because of the foreign support". On 27 February Arseny Yatsenyuk has become the prime minister of Ukraine, the provisional government was created.

If in the capital, support in northern, central and western regions of Ukraine the new Kiev authorities which have declared renewal of the movement towards the European integration were supported by the population and have quickly strengthened the position, then in the southeast a character of accession to power of the former opposition, its first decisions and the indulgence to revelry of ultranationalist organizations have caused a wave of discontent and protests of the population from the very first days after a change of the power in Kiev. In the Crimea on a wave of the public rise a change of executive bodies of the power of Sevastopol and the Autonomous Republic Crimea was made, and those, in turn, have refused to recognize the legitimacy of the new Ukrainian government and have addressed for assistance and help to the leadership of the Russian Federation. Within several followed weeks the independence of the Crimea was declared, the all-Crimean referendum was held, by the results of which the leadership of the sovereign independent Republic of Crimea has declared accession to Russia.

During the political crisis some heads of regions of Southeast Ukraine and political figures expressed the idea of Ukraine federalization and decentralization of the power as a possible exit from the current situation. Some Russian officials supported the idea of federalization.

After a change of the power in Kiev and formations of Yatsenyuk government, in cities of Southeast Ukraine have begun mass protest actions under the antigovernmental and pro-Russian slogans. As a result the Crimea AR and Sevastopol have proclaimed the independence and have joined to Russia, in a number of cities of the Southeast of Ukraine referenda on declaration of independence are also held and the inquiry for accession to Russia was sent. On April 14, 2014 A. Turchynov has signed the decree on carrying out the anti-terrorist operation in the east of Ukraine.

Since May, 2014 the active phase of military operations has begun where both national armed forces of Ukraine and recruited in the National Guard members of nationalist groups, and also international private military companies took part.

The position and the purposes of the USA during the emergence and increase of the crisis added up to the following. The discontent with the decision of the government of Ukraine to stop the process of preparation for signing the Agreement on association with the European Union was stated by many European officials, representatives of the leadership of the USA, PACE, European states. On 3 December the European Commission has declared that would not open new negotiations on the change of the text of the paraphed already agreement on association with Ukraine.

At the beginning of mass disorders the U.S. President's press secretary Jay Carney has declared that the administration of the USA does not consider disorders in Kiev as an attempt of the state revolution and insistently urges 
Ukrainian authorities to create conditions for citizens' free will.

As many political analysts think that the USA from the very beginning of events has been providing the financial and psychological support to participants of protest actions. Thus, some kind of rivalry in the influence on the opposition between the USA and the European Union took place.

On 30 January the State Department Spokesperson Jennifer Psaki has declared at the briefing that as the USA consider, despite feeling sick, the president of Ukraine Victor Yanukovich must continue negotiations with the opposition "for the formation of concrete steps on a peaceful settlement". The special attention is also deserved by the style of Mrs. J. Psaki's speech in which methods of the impact on the audience (Khachmafova, 2015) are purposely used, where the orientation to a certain ideal and anti-ideal (Ostrovskaya, 2015) is obvious. As she has claimed, the day before the U.S. Secretary of State John Kerry has carried out the teleconference with leaders of the Ukrainian opposition during which "the Secretary of State has emphasized the unconditional support to democratic aspirations of Ukrainian people in relation to association with Europe and has welcomed applications of these oppositional leaders directed against violence, their courageous work on protection of democracy, the progress in area of achievement of the objectives of a peaceful settlement" and also "has expressed a concern in messages on human rights violation". The USA demand the government of Ukraine to create the legal commission on investigation of these crimes and attraction of guilty to responsibility (Nikolaeva, Bogoliubova \& Shirin, 2015).

On 14 February the U.S. State Department has made the statement in which has urged to the formation in Ukraine "the multi-party technical government with an original division of powers and responsibility, which can deserve trust of Ukrainian people and restore political and economic stability". The document welcomed the announcement of release of all persons detained during the protests as "an important step to the de-escalation of intensity and creation of the space for peace, nonviolent solution of the political crisis in Ukraine".

On the last December the assistant to the Secretary of State Victoria Nuland has declared that America spent \$5 billion in the area of Ukraine. The USA direct financial streams mostly through non-governmental organizations which have to deal with human rights issues and issues on democracy. "The direct reason of the crisis in Ukraine, first of all, is the abnormal overthrow of operating Ukrainian authorities as a result of protesters' provocations from the Maydan Square, - the Deputy Foreign Minister of China Cheng Guoping considers - thus the western countries played a negative role in this process. And still I want to note that the Western world always use the double standards. It is impossible to ignore external influences, first of all, from the USA and other western countries, they try to influence Ukraine on order it will follow a way of the development of the country on the western democratic sample". The representative of Russia by the UNR V. Churkin has also accused the USA of the development of crisis in Ukraine.

In a consequence Washington has used more rigid methods in pressure upon the Ukrainian power at all points of the crisis settlement: release of all detainees for participation in mass riots, full reformatting of the most Ukrainian power including formation of the completely oppositional government, return to the constitution of 2004 and the need for carrying out early presidential elections is also declared.

The political legalization of neo-Nazi organizations, their conclusion from a shadow as a member of negotiations between the power and parliamentary opposition at preservation of the militarized underground by them, it is pointed as the main task of Washington. The information has appeared in mass media that the USA position on the current Ukrainian crisis is shown in intercepted negotiations of the western diplomats, in particular, V. Nuland with the ambassador of the USA D. Payette in Kiev, and also the general secretary of the European service of the external activity Helge Shmidt with the representative of the EU Jan Tombinsky in Ukraine. The most exhaustively it is described in the analytical material Stratfor "New Aspects of the American Foreign Policy concerning Russia".

The document shows that from the very beginning of the crisis Washington has chosen tactics of a "balance of forces". Americans, "having provided the financial and psychological support to protesters who have being protested against Yanukovich's decision to refuse closer relationships with Europe", and later, "having opposed government attempts to suppress demonstrations", have kept an opportunity for the change of the regime in Ukraine with the minimal participation and risk for the USA. Manifestation of determination from the point of view of Washington is the very introduction to the general balance system of internal political forces in Ukraine of ultranationalist and frankly neo-Nazi groups having (that is important) militarized formations. Their slogans and the line in relations with the power completely fit into the tactical line of the USA on stimulation of protesters' pressure upon the power. They only can set the current process of settlement more "resolutely", but radicals in order from their person to impose requirements to the authorities and to participate in political settlement, must be legalized. The sharp strengthening of the public activity of radicals and the statement their intentions confirm as yet their inclusiveness into American plans in Ukraine.

Thus, except rather responsible parliamentary opposition (UDAR and "Batkivshchina") and the legal, slightly subvarnished nazis from "Svoboda", to participation in the political process the third force - neo-Nazi "Right sector" is 
invited.

The submitted document "Stratfora" shows that Syria in which Islamic fighters put the power pressure upon the legitimate authority and wage terrible on cruelty terrorist war with the people, is a typical successful case of the balance strategy of forces in which the point of balance is displaced towards the extremism. The authors of this analytics absolutely quietly put it as a sample in one row with Ukraine.

Perhaps, settlement of the Ukrainian the crisis is not at all the purpose of intervention of the USA in internal political affairs of Ukraine. The purpose of Washington in Ukraine is to continue a geopolitical confrontation with Russia. For the western forces and the United States the fact that the president of Ukraine has decided to suspend the agreement signing on association with the European Union became critical. Europe was already ready to sign and change some articles of this contract in the course of negotiations and to start considering a ratio of Ukraine as a partner between Russia and the European Union that the United States do not strongly support, and, naturally, they were compelled to include this plan of carrying out protest actions.

As the former head of SBU of Ukraine Yakimenko think that Washington did not make peace in Ukraine and a position of the European Union which supported peaceful settlement of a situation in the country. "The USA did not make peaceful development of a situation in Ukraine, they did not support a position of the EU to hold peace talks, to pursue the peace policy (in the country). They did not support the relation of leaders of the EU, (the EU High Representative for foreign affairs and the security policy) Catherine Ashton, including her negotiations with Yanukovich as a legitimately governing president". The former head of the SBU has noted that the western politicians were constantly in Maidan and have being conducted continuous negotiations with the Ukrainian opposition." Initially the West behaved itself inconsiderately, in fact, being daily in Maidan, declaring for the whole world that the peaceful protest action is conducted, they have being encouraged with the presence occupations of buildings, they have being encouraged those actions which were carried out by radical forces", - Yakimenko has noted having reminded that "in fact so-called watch of the western politicians in Maidan was organized, they were not only in Maidan daily, but also acted from a scene".

The historical process during the centuries shows that the Ukrainian internal political environment is constantly characterized by sufficient decentralization and diversity.

Now in Ukraine there is a large number of non-governmental funds and organizations. Despite the declared openness, NGO created by Americans are closed structures.

Specially selected people ready for a reward in the form of various grants to present interests of the USA in other states are among the leading experts of such organizations. Involving the expert community and representatives of elite in its networks, the regular staff of non-governmental organizations (NGO) during discussions and debates gets all information about Ukraine on a state of affairs in political, economic, religious, social, military areas which is necessary for them. Then this information is studied in American analytical centers.

A large part of the Ukrainian funds is financed by such structures as USAID (The international development agency of the USA), NDI (National democratic institute), IRI (The international republican institute), NED (The fund of democracy development). Also the U.S. Embassy in Ukraine gives grants.

The special attention is paid to the international fund "Vozrozhdenie" realizing 500-600 projects a year by request of Americans. This is the non-governmental organization - George Soros's fund. The European commission has appointed the fund "Vozrozhdenie" by the manager of the funds allocated for the development of mass media, health protection, sociology and other socio-political directions of Ukraine.

It is supposed that the USA also use the Polish NGO as conductors of the American policy. Poland only helps the American non-governmental groups to expand its presence in Ukraine. The tasks remain the same: the collection of information and its transfer to the American analytical centers, thee formation in Ukraine the information field which is equitable to interests of the USA.

Americans support the patriarch Varfolomei in the interfaith dialogue of Universal and Moscow patriarchies and actively lobby an idea of the creation of the "unified local orthodox church" in Ukraine. Besides, Washington assists the RCC and the UGCC carrying out a proselytism policy in UOC MP territories.

Ukraine became an object of the activity of non-governmental organizations provoking extremism, separatism, nationalism, manipulating public consciousness up to the direct foreign intervention in internal affairs. By different estimates, today in Ukraine over 500 international NGO which as the main platform of its activity consider the Internet. A considerable part of NGO applies for defining the outlook of the whole Ukrainian society, and also the state policy. Long ago they became a tool of the foreign policy of the USA.

In the American reconnaissance community special interdepartmental groups, which are engaged in coordination of the activity of various NGO in Ukraine, are created and function. So, in the National Intelligence Council - NIC there is the National Intelligence for Russia and Eurasia. This division is directly subordinated to the director of the National 
intelligence and is responsible for preparation of the National prospecting report (National Intelligence Estimate) which is made on the basis of the open information and is regularly reported to the U.S. President.

Also in mass media there is periodically the information on presence of the American intelligence services in the territory of Ukraine, but this information is disproved by the government of intelligence services of the USA.

On pages of the American mass media the anti-Russian promotion is developed. On the first page of the "New York Time" magazine there were charges of the Russian power in a propaganda war. In the article entitled "Russia hurries to distort the truth about Ukraine", Hertsenkhorn derided Dmitry Medvedev for his post on "Facebook" with words that "blood in Ukraine was again shed ", and also about "the threat of a civil war".

The distorted statement of facts and events also ignores well documentary intervention of prominent officials of the USA including instigation of protesters in Kiev which is located in the western part of Ukraine and is thus adjusted in the most anti-Russian manner than the East of Ukraine where many ethnic Russians live and where there was Yanukovich's political base.

The assistant to the Secretary of State on the European affairs Victoria Nuland was the inspirer of revolt, reminding leaders of the Ukrainian business that the United States have invested 5 billion dollars in their "European aspirations"; discussing a question who must replace Yanukovich (its choice, Arseny Yatsenyuk became a new prime minister), and literally distributing to protesters buns in Maidan.

USAID is the main structure advancing the democratic regime in various countries. Organized in 1961 by the president Kennedy, it is the main conductor of nonmilitary help to other countries. In recent years the whole regions of the world were overflowed by a wave of protest movements, color revolutions and armed revolutions for fight against "bloody rehimes" and for celebration of "democratic values".

Also such organizations as the National Endowment for Democracy, NED, the National democratic institute, NDI, the International Republican Institute, IRI, the Freedom House, the Open Society Institute and some other accept a quite active role in the "advance of democracy".

For publicizing of the activity of data of structures in 2012 the research service of the USA Congressional Research Service has prepared the report "Foreign Aid: An Introduction to U.S. Programs and Policy".

As CRS says, "Foreign Aid: An Introduction to U.S. Programs and Policy", 2012 during the period from 2006 to 2010 the help from USAID on the "democratic" line more than a doubled from $\$ 1,7$ billion to $\$ 3,6$ billion a year. After that the recession was outlined. Thus, the problem in establishment of exact figures on financing of the advance of "democracy" in the world, even taking into account those data which were prepared for consideration in the Congress of the USA, is that the State Department allocates funds not only by means of the USAID programs.

The U.S. State Department manages the accounts of the Economic Support Fund, the Assistance for Europe, Eurasia and Central Asia, AEECA and the Democracy Fund. The volume of the funds allocated for carrying out transactions of these accounts in fiscal 2012 was $\$ 6,5$ billion. The western mass media repeatedly recognized that financing from the USA has played a serious role in protest movements of the last years.

The USAID report "Ukraine Country Development Cooperation Strategy 2012-2016" also gives quite interesting information: "USAID provides the largest volume of the donor help to the Verkhovna Rada of Ukraine and closely coordinates the efforts with other donors on strengthening of a role of the parliament of Ukraine. Westminster Foundation and European Commission's Ukraine-Legal Policy Advice Centre also participate in this work.

The USAID support is concentrated on aspects of the political development and the legislative reform, and also questions of an access and dialogue of citizens with the parliament of Ukraine. USAID is the largest donor who provides support on monitoring of political parties and elections in Ukraine. USAID cooperates with Canadian International Agency for Development, the Embassy of Germany, the Embassy of Great Britain, the Council of Europe, the European commission and OSCE in questions of the development of political parties and elections in Ukraine".

The total amount of the foreign help which is provided by the USA is annually measured by tens of billions of dollars.

Moreover, for the purposes of the advance of "democracy" it is pointed out much less than other problems of USAID. Of course, it is necessary to consider that moment that they are official figures, and the U.S. State Department and also other departments (including also $\mathrm{CIA}$ ) have the space for maneuvers in the form of registration of expenses on financing of the development of "democracy" under the form of other programs.

For Europe and its population the main instrument of the influence are mass media. The executive director of the "Institute of global prospects" at the Columbia University, professor, the doctor of philosophy Paul Cristi in conversation with the German mass media considers that the mood of the European population and, eventually, the success of the Ukrainian campaign for the USA now depend on the activity of mass media.

Proceeding from contents of the concept of "network wars" and the course of the Ukrainian crisis, it is now possible 
to make the following conclusions:

1. Americans have achieved partial success: by means of plot the unconstitutional change of the power in Kiev is made, the government of the country was legitimated taking an active anti-Russian position.

2. Ukraine is de facto in the condition of a civil war and as objects of the pseudo-legitimate state influence the Russian-speaking enclaves of the Southeast of Ukraine are defined. Ethnic cleanings are carried out. Russian as a symbol of the uniform Slavic historical past is almost under the threat of a ban. The country is split on a national, confessional and political sign. As the independent actor of the European and international policy Ukraine has stopped to exist. The matter is about disintegration of the state.

3. The status of the United Nations as the main international body urged to prevent military conflicts and humanitarian disasters has underwent the next stage of stagnation.

Again, since times of the Kosovan crisis of 1998-1999 years, despite the numerous appeals of the Constant representative to the UN from the Russian Federation about threats of escalation of conflicts and offers to hold peace talks between all interested parties, the UNO has not taken any effective measures on control of the USA and their allies. Americans also made impacts on all areas of a "network war" on permanent members of the Security Council with the purpose not to allow pinching of foreign policy positions of the USA in the expanding conflicts. No resolution of the UNO Security Council does not declare a destructive participation of the USA in the happening conflicts! The course of the USA on gradual weakening of the status and positions of the UNO as the body making decisions of the international level has once again achieved success. The international community more and more pays its attention to statements of incompetent representatives of State Department of the USA (for example, J. Psaki), than to decisions and resolutions of the UN Security Council. It is represented that abolition of the UNO and assignment of the status of the UNO on itself is one of the stages of realization of strategic problems of the USA on average and distant prospect.

4. The massive impact on political, economic and social interests of the Russian Federation is carried out.

Soon after the Russian intervention in a situation on the Crimean peninsula in February-March, 2014 and the Russian support of the unilateral declaration of independence of the Republic of Crimea and the following then entry of the Republic of Crimea into the structure of the Russian Federation and succession of events in the Southeast of Ukraine of the USA and their allies concerning the Russian Federation a number of steps of an economic, political and social character was undertaken.

In a conversation with the German mass media the executive director of the "Institute of Global Prospects" Paul Cristi has very indicative expressed his opinion that in case of the gradual reduction of economic relations of Europe with Russia, Europe will be compelled to reorient its economy on the USA because it is possible now to compare the economy of Europe on the volume and quality of goods only with the economy of America.

It will give a strong incentive to the development of the American economy that will allow beginning elimination of the American debts. But the cooperation must become the most important power Europe and USA. The refusal of Europe from Russian and Middle Eastern energy carriers will lead to the huge capital investments in the American production of slate gas, will lead to creation of the powerful infrastructure on its processing and delivery to Europe. Europe will be interested in the fastest creation of such infrastructure and will also not stint expenditure that will allow the USA to quickly liquidate the financial problems. The refusal of Europe from the cooperation with America is difficult presented - Europe too strongly depends on the USA in political, military and economic relation. And except the participation in the NATO structure, there is also a moral debt of Europe to America which has once rescued it from totalitarianism and provided Europe the comfortable existence.

Thus, the Ukrainian internal political crisis became perhaps the regular reference point of an attempt to build a new world order, a new control system "An axis Washington - the rest of the world".

Thus, the maximum application of efforts is directed on economic and political weakening of the Russian Federation and advance of the advanced parts of NATO to the Russian borders, and ESDP complexes - to areas of basing of parts of the strategic purpose of the Russian Federation that creates the direct threat for the military security of the state. Economic losses of our country and people should be still estimated as well as to realize the system of measures developed by the Government of the Russian Federation on minimization of a damage from actions of the USA and their allies.

\section{Discussion}

The emergence of "network wars" has caused the expansion of a range of asymmetric threats in the modern world. As a result of the analysis of the current and perspective threats the American government has created a new system of views 
on realization of national interests by the power and nonpower influence ("emerging theory of war"). There was a concept " soft power" - "the soft force", a combination of nonviolent methods of the influence (secret diplomacy, for example) with the possible threat of power scenarios realization.

It is very indicative on the matter the former statesman of the USA Zbignev Bzhezinsky has expressed his opinion. Analyzing a geopolitical situation in the modern world and modeling possible options of various countries' actions and their unions in the future, he has noted that the American geopolitical strategy along with the other will be provided by "the additional benefit of the use in its interests of the again created network of international relations which is considerably developing outside the more traditional system of national states".

As the western ideologists think wars of the information epoch are based on conscious integration of all four areas. From them the network, which is the basis of "network war" operations realization, is also created.

Dugin A.G. notes that, in fact, creation of a concept of "network wars" in that sense in what it is meant by strategists of the USA, is a forming of the system of global domination of the USA over the whole world, i.e. the postmodernist analog of colonization and submission which was only carried out in new conditions, in new forms and with the use of new means. Here the direct occupation, the mass input of troops or territories occupation are not at all necessary. Army actions and huge military expenditure are excessive. The network is more flexible weapon, it manipulates violence and military force only in extreme cases, and the main results are reached in contextual influence on a wide set of factors -which are information, social, cognitive, etc.

\section{Conclusion}

Having regard to the above, it is necessary to state the following:

1. The concept of "network wars" as the system of views and concrete measures for realization of the USA geopolitical ambitions has proved its efficiency, and tactics of projection of "soft" and "sharp" force concerning objects of the external influence will be further used.

2. Despite the active foreign policy position directed on hardening of peace and security in Eurasia and in the World, the Russian Federation has once again remained "face to face" with its geopolitical opponents - the USA and their allies who brought the powerful political and economic blow down our country.

3. One of the consolidating purposes of the USA and the European Union influence was the Customs union where the West has saw the threat for the central situation in the system of the world trade. Perhaps, this influence was the prevention not only to the European and Asian states which have the ability of integration in its framework and the weakening of a role of the European and American lobby in the economy, but also for the Latin American countries with difficult interstate social processes (for example, Argentina) and to all the world community in general. A signal that the USA with all its determination are going to cover the national debts only at the expense of the world community.

It should be noted that rather quiet times of the 90-2000s ended. The democracy "in American manner" has showed once again its true greedy and aggressive essence, but already directly near the Russian borders.

At the same time, the hidden aggression of the USA and their allies from the European Union concerning Ukraine and the attempt to create the destructive socio-political background in our country must have the boomerang effect. The historical process shows what exactly during the periods of the hardest trials fraternal people of Russia, Ukraine and Belarus have consolidated the efforts in their overcoming and showed the best national qualities in the joint creative fight for the future.

Proceeding from it, we can note that "network wars" refer to a kind of modern deviation processes which transform the modern society under the influence of the use of "psychological weapon" in the Internet space, therefore a real and not virtual social and economic situation both in the country and in the world changes.

\section{References}

Artemev, A. Kak SShA i Evrosoyuz vmeshivayutsa v situatsiyu na Ukraine. http://world-politik.livejournal.com/67127.html

Bugeja, M. (2015) Interpersonal Divide: The Search for Community in a Technological Age. Oxford. pp. 240.

Bzhezinsky, 3. (1999) Velikaya shahmatnaya doska. Gospodstvo Ameriki i ego geostrategicheskie imperativy. M.: "Mezhdunarodnye otnosheniya", 1999.

Churkin has accused the USA of hiding the truth about their role in the crisis in Ukraine.//Delovaya gazeta «Vzglyad», 15 March $2014 \mathrm{y}$. http://vz.ru/news/2014/3/15/677247.html

Gabdrafikov, I.M., Karabulatova, I.S., Khusnutdinova, L.G. \& Vildanov, Kh.S. (2015) Ethnoconfessional Factor in Social Adaptation of Migrant Workers in the Muslim Regions of Russia. In the: Mediterranean Journal of Social Science. 2015. Vol 6, No3, 
Supplement 4, May 2015. pp. 213-223.

Garstka, J. \& Alberts, V. Network Centric Operations Conceptual Framework. Version 2.0. http://www.dodccrp-test.org/ccrp-books/

Gerber, D. (2010) Global competition: Law, Markets and Globalization. Oxford. pp. 350.

Dixon, Jeffrey C., Singleton, Royce, A. \& Bruce, C. (2015) Straits. The Process of Social Research. Oxford. pp. 512.

Dugin, A.G. (2006) Teoriya i praktika setevoi vojny i ee vliyanie na situatsiyu v YuFO. Centr sistemnyh regionalnyh issledovany i prognozirovaniya IPPK RGU i ISPI RAN: Sobranie trudov «Yuzhnorossiiskoe obozrenie», edition 34 «Setevye strategii Zapada na yuge Rossiì.

Eks-glava SBU: k vlasti na Ukraine prihodyat lyudi, kotoryh naznachayut ne na maidane, a v SShA.//Mezhdunarodnaya panorama. http://itar-tass.eom/mezhdunarodnaya-panorama/l 041789.

Ezhenedelnik «Evropeisky ekonomichesky vestnik». Intervyu s doktorom filosofii P. Kristi, mart 2014. http://rusmir.in.ua/pol/5496ukrainskiy-kapkan-i-buduschee-rossii.html

Ishhenko, R. Ukrainsky krizis i ego rol dlya SNG i mira. http://vybor.ua/article/vneshnjaja_politika/ukrainskiy-krizis-i-ego-rol-dlya-sng-imira.html

Karepova, S.G., Karabulatova, I.S., Novikov, V.S., Klemovitsky, S.V., Stratan, D.I. \& Perova, A.E. (2015) New Approaches to the Development of Methodology of Strategic Community Planning. In the: Mediterranean Journal of Social Science. 2015. Vol 6, No3, S.6. pp.357-364.

Khachmafova, Z.R., Karabulatova, I.S., Luchinskaya, E.N. \& Osipov G.V. (2015) Gender Features of Discourse of Woman's Literature as a Reflection of Changes in the Modern Society. In the: Mediterranean Journal of Social Science. 2015. Vol 6, No3, S.2, May 2015. pp. 476-481.

Korovin, V. (2014) Tretya mirovaya setevaya voina. SPb.: Saint-Petersburg.

Kortunov, A. SShA v ukrainskom krizise. http://www.pravda.ru/news/expert/22-04-2014/1205375-kortunov-0/

Markov, S. (2014) Politolog. Glavnaya tsel SShA - voina mezhdu Rossiei i Ukrainoi/Vechernyaya Moskva, 8 April 2014 y. http://www.vm.ru/news/2014/04/08/politolog-sergej-markov-glavnaya-tsel-ssha-vojna-mezhdu-rossiej-i-ukrainoj-243311.html.

Nikolaeva, J. V., Bogoliubova, N. M., \& Shirin, S. S. (2015). Ecological tourism in the state image policy structure. experience and problems of modern Russia. Current Issues in Tourism, doi:10.1080/13683500.2015.1100588

Ostrovskaya, T.A., Karabulatova, I.S., Khachmafova, Z.R., Lyaucheva, S.A. \& Osipov G.V. (2015) The Discourse of the Russian Elite in the ERA "Liquid" Modernity as a Problem of Ethnic, Social and Cultural Security. In the: Mediterranean Journal of Social Science. 2015. Vol 6, No3, S4, May 2015. pp. 147-154.

Pismennaya, E.E., Karabulatova, I.S., Ryazantsev, S.V., Luk'yanets, A.S. \& Manshin R.V. (2015) Impact of Climate Change on Migration from Vietnam to Russia as a factor of Transformation of Geopolitical Relations. In the: Mediterranean Journal of Social Science. 2015. Vol 6, No3, S.2, May 2015. pp. 210-215.

Pocheptsov, G.G. (2001) Teoriya kommunikatsii. M.: Refl-buk.

Politichesky krizis na Ukraine.//Rossijskaya gazeta, May 2014 y. http://www.rg.ru/sujet/5113/

Polishhuk, O. (2014) SShA-Ukraina: ruchnoe upravlenie. Centr politicheskogo analiza ITAR-TASS. 22 April 2014. http://tassanalytics.com/positions/2103

Ryazantsev, S.V., Pismennaya, E.E., Karabulatova, I.S. \& Charif Y.Akramov. (2014) Transformation of sexual and matrimonial behavior of Tajik labor migrants in Russia. In the: Asian Social Science. Vol 10, No.20.

Ryazantsev, S.V., Karabulatova, I.S., Sivoplyasova, S.Yu., Pismennaya, E.E. \& Manshin, R.V. (2015) Modern Aspects of Human Trafficking in the Context of Labor Exploitation and Irregular Labor Migration in the Russian Federation. In the: Mediterranean Journal of Social Science. 2015. Vol 6, No3, S.2, May 2015. pp. 67-72.

Ryazantsev, S.V., Karabulatova, I.S., Mashin, R.V., Pismennaya, E.E. \& Sivoplyasova, S.Yu. (2015) Actual problems of human trafficking in Illegal immigration in the Russian Federation. In the: Mediterranean Journal of Social Science. 2015. Vol 6, No3, S.1, May 2015 (a). pp. 621-626.

Ryazantsev, S.V., Karabulatova, I.S., Ter-Akopov, A.A., Pismennaya, E.E., Bozhenko, V.V. (2015) The specificity of the differential regulation of economic integration in the context of contemporary labor migration. In the: Mediterranean Journal of Social Science. 2015. Vol 6, No3, May 2015. pp. 96-102.

Syomin, N.L. (2011) Spetssluzhby i krupnyi biznes SShA. Rossiya i Amerika v XXI veke. №1, 2011. http://www.rusus.ru/?act=read \&id $=230$.

Skolko stoit "demokratiya" ot SShA. Redaktorskaya kolonka. Vesti - Ekonomika. 24 April 2014y. http://www.vestifinance.ru/articles/ 42108

Ukrainsky krizis: shest strashnyh stsenariev.// Ezhenedelnik «Ekspert», 8 March 2014y. http://expert.ru/expert/2014/11/shest-stsenariev/

Fond strategicheskoi kultury, elektronnoe izdanie. Amerikanskie NPO na Ukraine - instrumenty politiki SShA. http://www.fondsk.ru/pview/ 2011/08/25/vlijanie-cherez-socialnye-seti-i-eksport-revoljucii-4424.html

Zamaletdinov, R.R., Karabulatova, I.S., Yarmakeev, I.E. \& Ermakova, E.N. (2014) Linguo-propaedeutics of ethnic conflicts as a basis for stability in complex polyethnic regions. In the: Asian Social Science. Vol.10, No.20, 164-173. http://www.ccsenet.org/journal/ index.php/ass/article/view/40805/22526 